\title{
LANDED PROPERTY OF CHURCHES AND DENOMINATIONAL ASSOCIATIONS IN POLAND
}

\author{
BENICJUSZ GŁĘBOCKI \\ Adam Mickiewicz University, Institute of Socio-Economic Geography and Spatial Management, \\ Poznań, Poland \\ Manuscript received May 20, 2010 \\ Revised June 6, 2010
}

GŁęBOCKI B., Landed property of churches and denominational associations in Poland. Quaestiones Geographicae 29(2), Adam Mickiewicz University Press, Poznań 2010, pp. 39-54, 3 Figs, 5 Tables. ISBN 978-83-232-2168-5. ISSN 0137-477X. DOI 10.2478/v10117-010-0013-6.

\begin{abstract}
Historical factors are presented that have determined landed property belonging to churches and denominational associations in Poland. The article then moves to post-war times to discuss the size and structure of church property resources in 1950, before its appropriation by the State in 1952, and after its restoration to the ecclesiastical owners following the systemic transformation of 1989 . The form and ways of recovery of church property are discussed, as well as its present size, structure and distribution.
\end{abstract}

KEYWORDS: church land, Poland, historical determinants

Benicjusz Głębocki, Institute of Socio-Economic Geography and Spatial Management, Adam Mickiewicz University, ul. Dzięgielowa 27, 61-680 Poznań, Poland, e-mail: beni@amu.edu.pl

\section{Introduction}

Land resources of Polish churches and denominational associations ${ }^{1}$ are closely connected with the number of their respective believers and with their histories in Poland. The situation of broadly understood church property is not only complex, but often also complicated, owing to the great number of churches and denominational associations operating in Poland, and to the relations holding among them (as well as between them and the State in the history of the country).

\footnotetext{
${ }^{1}$ In the further part of the article the author uses the phrases 'church land / estate / property /immovables' to denote the property of all the churches and denominational associations based in Poland.
}

This has often given rise to various long-drawnout conflicts and prejudices.

In Poland, the dominant role in the ownership structure is played by the Roman Catholic Church, but in some regions also other churches and denominational associations are major proprietors. At various moments in Polish history, also Lutheran and Orthodox churches as well as Jewish communities have played a significant part here.

The distribution and resources of landed property belonging to churches and denominational groups are greatly determined by historical factors. The property of the Roman Catholic Church is among the oldest; it appeared in the Polish lands almost simultaneously with Christianity. Initially 
the Church met with no obstacles in acquiring land, but as early as the 13th century the nobility started to object to land being conveyed to church institutions. In 1635 they passed the first amortisation act in Poland forbidding the Church to buy the land of the nobility, establish new foundations, and expand the existing ones. Especially hit by the act were monastic communities, and the only type of body excluded from it was chapters (Dudziak 1989). As Dudziak notes, successive amortisation acts passed by the Sejm in the 16th and 17th centuries followed a similar line. A limitation on the increase in Church possessions was also stipulated by a programme of State reform, the so-called Zamojski Code, which, however, was not backed by the Sejm in 1780. It was the last attempt at amortisation legislation in pre-partition Poland.

Another type of ecclesiastical property going back to an equally distant past in the Polish lands is that of Jewish communities. As early as 1264 , the Kalisz Statute issued by Boleslaus the Pious guaranteed to the Jews living in Poland the inviolability of cemeteries and their protection. This act was of prime importance to the Jewish population moving to Poland because of the deeply rooted principles of Judaism².

In the period of the partitions, the situation of the churches operating in the Polish lands differed. At that time amortisation acts started to differ regionally because of their adjustment to the legislation of the respective partitioning power. The changes made by those powers in church property have proved to be extremely enduring despite the lapse of time and various historical developments (cf. Figs 1 and 2).

After Poland regained its independence in 1918, all legal rules of the partitioning powers directed against the Roman Catholic Church were abolished. New principles of relations between the churches and the State were set out in the Constitution of March 19213; the Constitution of April 1935 made no change in them. The

\footnotetext{
${ }^{2}$ In contrast to Christianity, which permits for a grave to be disturbed after a specified period and a for new burial to take place, or even for entire cemeteries to be liquidated if not used for a long time, in Judaism cemeteries are inviolable and of unlimited duration. They last as long as their location is known. Human remains are exhumed extremely rarely and for very special reasons only.

${ }^{3}$ The constitutional formula (Art. 114) guaranteed to the Catholic Church "a leading position among equal faiths".
}

Concordat signed with the Vatican State in 1925 confirmed that the Church was free to possess, purchase and sell landed property in accordance with canon law and the laws in force in Poland. It was also stipulated that ecclesiastical legal persons were obliged to sell to the State that part of their agricultural land which was in excess of the norms set for them ${ }^{4}$ for the purposes of land reform. Those Concordat stipulations were regarded as a new amortisation act.

The recovery of church property confiscated by the governments of the partitioning powers was to be settled by separate acts at a later date. To this end, in accordance with the Concordat stipulations, in 1931 a Mixed Commission composed of representatives of the government and the Catholic Church was set up to address issues this would involve. The first task the Commission was expected to tackle was the problem of so-called post-Uniate property, which used to be the property of the Catholic Church and became State property on regaining independence. A claim to those lands was also advanced by the Autocephalous Orthodox Church. The Mixed Commission felt unauthorised to settle the matter of the legal status of that estate; at a joint meeting with the Papal Commission on 24 April 1932 it was left for a separate agreement to resolve. However, because of the unyielding position of the government side, the Papal Commission gave up claims to the disputed 'Orthodox land' in favour of the State.

One of the first acts on the strength of which the property confiscated by the partitioning powers was to be restored was that of 1932, 'On Property Confiscated by the Former Partitioning Governments from Participants of the Struggle for Independence'. It only gave the right to repossess property to freedom fighters, but because of their age, the situation in the country in the Great Depression period and the aura of the approaching world war, the act never entered into force (Wisłocki 1981).

At this point it might be mentioned that the Constitution of 1921 obliged the Polish State to finance benefices for the land lost as a result of confiscation by the partitioning powers (Wisłocki 1981; Rybarczyk 1981).

${ }^{4}$ Parishes had the duty to sell land in excess of 15-30 ha (depending on its farming value), while for bishops' mensae, chapters and seminaries this limit was 180 ha. 


\section{Church property after the Second World War}

After the Second World War, the Council of Ministers of the Provisional Government of National Unity issued a declaration on 12 September 1945 on the strength of which the Concordat with the Vatican State lost force. The legal gap in the State-Church relations was filled with a variety of administrative acts that had no foundation in legislation.

The first limitation of the property rights of churches and denominational associations was the decree of 6 September 1946, 'On the Agricultural System and Settlement on the Western and Northern Territories', on the strength of which post-German church estate was nationalised. In turn, the act that came into force on the territories belonging to the Polish State before the Second World War and after it finished was that of 20 March 1950, 'On the Takeover by the State of Mortmain Estate, Guarantee to Parish Priests of the Possession of Farms, and the Establishment of the Church Fund'; on its strength those lands whose area exceeded the ceilings set up in the decree of 6 September 1946 were nationalised.

At this point it would be well to give a short outline of the genesis and history of real estate held in mortmain ('dead hand') in Poland ${ }^{5}$. This type of estate developed as a result of rulers conveying the ownership of land to ecclesiastical hierarchs and religious orders settled in Poland. The amortisation acts passed in the 16th and 17th centuries limited the sale and gifts of land to the clergy, but did not cause a marked shrinkage of church property. In the Enlightenment period there appeared ideas of reorganisation of the Catholic Church, which were soon followed by attacks on religious orders, especially contemplative, in the whole of Europe. In accordance with the ideas propounded, attention increasingly focused on public usefulness of religious orders, especially in the fields of education and hospital care. The attacks intensified after the suppression of the Jesuits in 1773 and the secularisation of their

${ }^{5}$ Land which was property of ecclesiastical legal persons, inalienable and uninheritable, thus precluding many economic benefits. That is why as early as the 9th century secular legislation started to call it 'land in mortmain (dead hand)'. vast wealth. This occurrence initiated the shrinkage of mortmain. However, in Poland this process took a milder course, apart from the suppression of the Jesuits, because of the strong position of monasteries and convents in society. It was only in the period of the partitions that this process intensified (cf. http://www.zakony.katolik.pl), and a larger-scale dissolution of religious orders took place in the Congress Kingdom of Poland in 1819. The suppression embraced then about 50 of the wealthiest monasteries and convents; those left were mainly mendicant orders. The Catholic Church suffered further losses of property in the Russian sector after the November Insurrection of 1831. The annexationist's reprisals included not only the suppression of still more religious orders, but also diocese churches. By the January Rising of 1863, about 160 monasteries and convents survived, of which 122 were homes of mendicant orders. Further reprisals, combined with the Russification of society, were responsible for the fact that by the beginning of the 20th century a mere 8 monasteries and convents had survived. The seized property was transferred to the Orthodox Church, which was given the rights of a dominant denomination. In 1839 the Czarist authorities persuaded the Uniate metropolitan Józef Siemaszko to convert to Orthodoxy, together with the faithful and the landed property possessed. A proportion of the confiscated or appropriated lands were sold (Kieniewicz 1983).The suppression of religious orders and the takeover of the Catholic Church property had a different character in the Prussian sector. Here this process was one of the manifestations of the policy of Germanisation of Polish society and the weakening of the position and importance of the Catholic Church relative to the dominant Protestant Church.

In the Austrian sector, owing to the Josephinian reform implemented there, the Catholic Church, and especially its property, was largely made subordinate to the State authority (Jabłońska-Deptuła 1987).

After the Second World War, the first limitations on church property resources started with the already-mentioned area ceilings imposed by the decree of 1946. In central, eastern and southern voivodeships they amounted to 50 ha for farms of parish priests and 5 ha for those of religious houses, while in the western voivodeships 
Table 1. Church agricultural land in 1950 (before its appropriation by the State)

\begin{tabular}{|c|l|c|c|}
\hline \multicolumn{1}{|c|}{ Churches and denominational associations } & Ha & ( \\
\hline 1 & Catholic Church & $154,930.3$ & 87.22 \\
\hline 2 & Catholic Church of Greek (Uniate) rite & 13,982 & 7.87 \\
\hline 3 & Evangelical churches & $5,064.4$ & 2.85 \\
\hline 4 & Polish Autocephalous Orthodox Church & $2,830.6$ & 1.59 \\
\hline 5 & Jewish religious communities & 588.3 & 0.33 \\
\hline 6 & Mariavite churches & 118.4 & 0.07 \\
\hline 7 & Catholic Church of East-Slavonic (neo-Uniate) rite & 61.6 & 0.04 \\
\hline 8 & Muslim Religious Association & 30.4 & 0.02 \\
\hline 9 & Polish Church of Baptist Christians & 21.1 & 0.01 \\
\hline 10 & Polish National Catholic Church & 6.7 & 0.00 \\
\hline 11 & Mennonite communities & 6.2 & 0.00 \\
\hline 12 & Old Catholic Church & $\mathbf{1 7 7 , 6 4 0 . 3}$ & $\mathbf{1 0 0 . 0}$ \\
\hline 13 & Eastern Old Believers' Church & 0.1 & 0.00 \\
\hline 14 & Methodist Church & 0.1 & 0.00 \\
\hline Churches and denominational associations jointly & 0.1 & 0.00 \\
\hline
\end{tabular}

Source: The Liquidation of the Church Fund Act of 1 January 2005.

of Pomerania, Poznań and Silesia the limit was 100 ha. A further limitation was introduced by a decree of 24 April 1952, 'On the Winding Up of Foundations', on the strength of which immovables belonging to ecclesiastical foundations were nationalised.

One of the methods employed by the State authorities to deprive ecclesiastical legal persons of their property was all kinds of legal acts. Those acts allowed them to take over church property for such offences as, e.g., failing to fulfil the duties imposed on those persons by the State ${ }^{6}$.

At the start of 1950, the area of farmland of all the churches and denominational associations amounted to $177,640.3 \mathrm{ha}$, of which the mortmain estate of the Catholic Church occupied about 167,000 ha (Table 1) ${ }^{7}$. A dominant role in the ownership structure was played by the Catholic Church $-87.2 \%$, while the Catholic Church of the

${ }^{6}$ For instance, pieces of property were taken away if their owners failed to pay excessive income taxes, housing taxes, taxes on parish and school buildings, and on cemeteries. Church property was also seized as a result of the secularisation of schools and nursing homes. htm
Greek (Uniate) rite came a distant second - 7.9\%. The possessions of the other churches - Evangelical and the Polish Autocephalous Orthodox Church - were insubstantial, and of some denominational associations, practically symbolic. Also modest was the property of Jewish communities, which had then a mere 588.3 ha of farmland. This is a convenient point to note that the land resources of Jewish communities are usually limited to the premises of synagogues, cemeteries and other places of religious cult.

\section{Recovery of church property after the systemic changes of 1989}

As a result of the systemic changes of 1989, all the restrictions on property rights of ecclesiastical legal persons introduced by the communist authorities were annulled. Moreover, The State's Relation to the Catholic Church Act of 17 May 1989 guaranteed, and set rules for, the recovery of the lost property, or alternative property, or the payment of just compensation. Ecclesiastical legal persons were also given the right to buy, sell and 
manage their assets. Applications for the recovery of church property were accepted until the end of 1992, when a Property Commission was set up to consider individual applications; its members are representatives of the Polish government and the Secretariat of the Polish Episcopate. The Commission has been sitting ever since; with the numerous problems resulting from changes that took place after the nationalisation and development of church land by other users, its task is formidable and will certainly take long. After its decision (judgement) of recovery, the land can be entered in a property register. The provisions of the Act of 17 May 1989 were confirmed in the Concordat with the Vatican State, concluded in 1993 and ratified by Poland in 1998 (Uruszczak \& Zarzycki 2003). Similar solutions, backed by appropriate legal acts, have been employed in the case of the remaining churches and denominational associations operating in Poland ${ }^{8}$.

The Act of 17 May 1989 that has changed the rules applying to church property is a sort of compensation for the losses the churches suffered as a result of the 1950 Act and other legal acts passed by the communist authorities. In particular, it provides for a restoration of benefice lands of up to 50 or 100 ha, depending on the region. The lands can be returned in kind at the place of their location if they were ecclesiastical property in the past, or by way of exchange if former church land is now being used by current owners for other purposes. Then, following court judgements in force, or issued under various titles, the Church concludes an agreement with the Treasury's Agricultural Real Estate Agency for land from its reserve that the Church has never

\footnotetext{
${ }^{8}$ Property matters of the particular churches were regulated in the years 1991-1997 by several acts called ecclesiastical. In the case of the property of the Autocephalous Orthodox Church, this was done on the basis of articles 46 and 48e of The State's Relation to the Polish Autocephalous Orthodox Church Act of 4 July 1991; the Act of 13 May 1994 took care of the land of the Augsburg Evangelical Church (articles 39 and 45a) and the Reformed Evangelical Church (articles 23 and 26b); the Act of 30 June 1995 concerned the Church of Baptist Christians (articles 39 and 43), the Evangelical Methodist Church (articles 35 and 37), the Seventh-day Adventist Church (articles 33 and 35), and the Polish Catholic Church (articles 33 and 34); the Act of 20 February 1997 regulated property matters for Jewish Religious Communities (article 29), the Catholic Mariavite Church (article 29), the Old Catholic Mariavite Church (article 32), and the Pentecostal Church (articles 35 and 36).
}

owned (called 'replacement land') and which is situated elsewhere. In the Western and Northern Territories, churches were granted some land (connected with church buildings and cemeteries) already in $1971^{9}$. Now, on the strength of the 1989 Act, ecclesiastical legal persons that started work in those regions after 8 May 1945 could apply for free ownership of land from the Treasury's Agricultural Property Reserve ${ }^{10}$.

It should be noted that the land the Catholic Church gets back is mostly mortmain estate appropriated by the State after the Second World War. Under the denominational law in force, there can be no return of lands taken away from the Church by the partitioning powers and developed by other users.

As has already been mentioned, historical developments and current legislation, especially its implementation, have contributed to the present-day distribution of land owned by churches and denominational associations. Another influential factor is the state and continuity of land registers, especially in areas of the former Austrian and Prussian sectors (Figs 1 and 2). As of 1 January 2007, church-owned land could be found in a total of 2,993 territorial units, but the plots were small in area. In 862 units they did not even exceed 10 ha, and in 112 towns and communes they covered more than 200 ha. And out of the 27 towns and communes in which church property occupied in excess of $400 \mathrm{ha}^{11}$, 21 were situated in regions that were part of the Polish State also before the Second World War, with 13 of them located in Kujavia-Pomerania and Wielkopolska. Those voivodeships had a substantial proportion of benefice lands before their nationalisation on the one hand, and considerable reserves of Treasury land on the other. The latter made it easier to return former benefices on exchange principles.

${ }^{9}$ The Land Granting Act of 1971 (Article 60) disposed of property left in the Western and Northern Territories by Protestant churches.

${ }^{10}$ Under Article 70a, the total area of the farmland thus acquired and the land already possessed cannot exceed the set limits. In the case of parish farms, this is 15 ha; diocese farms, 50 ha; farms of seminaries run by dioceses and religious orders, 50 ha; farms run by religious houses, 5 ha; when they are engaged in charitable activity, 50 ha.

${ }^{11}$ Cracow, 767 ha; and Warsaw, 534 ha. 


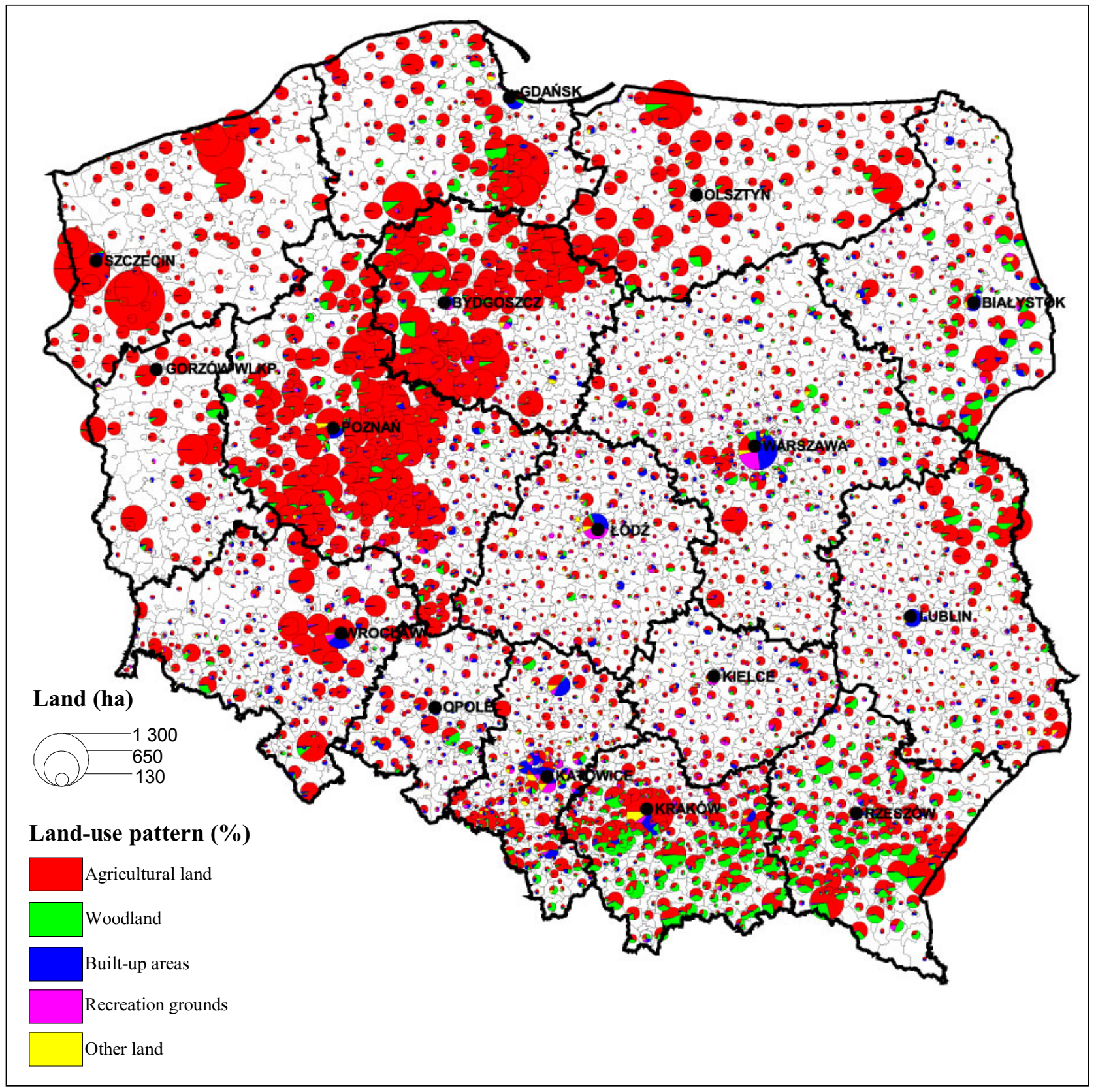

Fig. 1. Church land in 2007: Resources and use pattern

Church property accounts for the largest proportion of total agricultural land in the communes under the jurisdiction of the archdioceses of Gdańsk (Pelplin and Toru dioceses), Gniezno (Gniezno and Bydgoszcz dioceses), and Poznań (Poznań and part of Kalisz dioceses). The three archdioceses are situated within three voivodeships: Kujavia-Pomerania, Pomerania and Wielkopolska. Church property in those voivodeships occupies a total of 45,900 ha, which makes up $37.3 \%$ of the national ecclesiastical resources (Table 2).
In none of the voivodeships does church property exceed $1 \%$ of their total area. The index is the highest in Kujavia-Pomerania, at $0.92 \%$, and the lowest in Łódź, at $0.2 \%$.

Church property can also be observed to be more substantial in the voivodeships of Małopolska and Subcarpathia, especially in the archdioceses of Cracow (Cracow, Tarnów and Bielsko-Żywiec dioceses) and Przemyśl (Przemyśl and Rzeszów dioceses) ${ }^{12}$. Church land resources

\footnotetext{
${ }^{12}$ Without the southern part of Silesia - the Bielsko-Żywiec diocese.
} 
TABle 2. Church LAND in 2007: Resources AND USE PATtern

\begin{tabular}{|c|c|c|c|c|c|c|c|c|c|}
\hline \multirow{4}{*}{ Voivodeship } & \multicolumn{9}{|c|}{ Church land } \\
\hline & & \multicolumn{2}{|c|}{ of which share in: } & \multicolumn{6}{|c|}{ of which: } \\
\hline & & \multirow{2}{*}{$\begin{array}{c}\begin{array}{c}\text { total } \\
\text { church } \\
\text { land }\end{array} \\
\%\end{array}$} & \multirow{2}{*}{$\begin{array}{c}\begin{array}{c}\text { total } \\
\text { voivode- } \\
\text { ship land }\end{array} \\
\%\end{array}$} & \multicolumn{2}{|c|}{$\begin{array}{l}\text { agricultural } \\
\text { land }\end{array}$} & \multicolumn{2}{|c|}{$\begin{array}{l}\text { woodland and } \\
\text { tree clusters }\end{array}$} & \multicolumn{2}{|c|}{ urbanised areas } \\
\hline & & & & ha & $\%$ & ha & $\%$ & ha & $\%$ \\
\hline Poland & 132,434 & 100.0 & 0.42 & 102,060 & 77.1 & 12,758 & 9.6 & 14,172 & 10.7 \\
\hline Lower Silesia & 7,058 & 5.3 & 0.35 & 3,342 & 81.0 & 301 & 4.3 & 1,003 & 14.2 \\
\hline Kujavia-Pomerania & 16,543 & 12.5 & 0.92 & 6,816 & 87.6 & 877 & 5.3 & 750 & 4.5 \\
\hline Lublin & 6,906 & 5.2 & 0.27 & 3,221 & 72.5 & 641 & 9.3 & 913 & 13.2 \\
\hline Lubuska Land & 3,659 & 2.8 & 0.26 & 1,544 & 90.0 & 111 & 3.0 & 220 & 6.0 \\
\hline Łódź & 3,598 & 2.7 & 0.20 & 7,842 & 62.5 & 180 & 5.0 & 994 & 27.6 \\
\hline Małopolska & 10,259 & 7.7 & 0.68 & 21,700 & 55.5 & 3,146 & 30.7 & 1,229 & 12.0 \\
\hline Mazovia & 8,244 & 6.2 & 0.23 & 8,313 & 64.1 & 911 & 11.1 & 1,768 & 21.4 \\
\hline Opole & 2,282 & 1.7 & 0.24 & 1,535 & 67.3 & 160 & 7.0 & 569 & 24.9 \\
\hline Podkarpacie & 9,491 & 7.2 & 0.53 & 6,025 & 63.5 & 2,383 & 25.1 & 977 & 10.3 \\
\hline Podlasie & 5,436 & 4.1 & 0.27 & 3,342 & 61.5 & 977 & 18.0 & 1,017 & 18.7 \\
\hline Pomerania & 8,284 & 6.3 & 0.45 & 6,816 & 82.3 & 676 & 8.2 & 517 & 6.2 \\
\hline Silesia & 5,507 & 4.2 & 0.45 & 3,221 & 58.5 & 512 & 9.3 & 1,500 & 27.2 \\
\hline Świętokrzyska Land & 2,411 & 1.8 & 0.21 & 1,544 & 64.0 & 101 & 4.2 & 683 & 28.3 \\
\hline Warmia-Mazuria & 9,028 & 6.8 & 0.37 & 7,842 & 86.9 & 424 & 4.7 & 438 & 4.9 \\
\hline Wielkopolska & 24,811 & 18.7 & 0.83 & 21,700 & 87.5 & 1,260 & 5.1 & 1,321 & 5.3 \\
\hline West Pomerania & 8,917 & 6.7 & 0.39 & 8,313 & 93.2 & 98 & 1.1 & 274 & 3.1 \\
\hline
\end{tabular}
ships.

Source: Own compilation based on data from Land register. Collective lists as of 1 Jan. 2007 by commune. Marshals' Offices of all voivode-

are smaller here than in the Pomerania-Wielkopolska region, at 19,500 ha $(14.9 \%$ of the national ecclesiastical resources), and highly scattered owing to the agrarian structure typical of Małopolska. The greatest concentration of church land can be found in the city of Cracow, as well as the towns/ communes of Kalwaria Zebrzydowska (402 ha), Dukla (424 ha), and Fredropol (486 ha). While in Cracow and Kalwaria Zebrzydowska these are benefices that have been church property for centuries, in the case of Dukla and Fredropol this is consolidated land that the Przemyśl archdiocese has obtained from the Treasury Reserve under the exchange programme.
Worth noting is also a relatively high proportion of church property in some communes of West Pomerania, Warmia-Mazuria and Lubuska Land. An example is the communes of Pyrzyce and Kołbaskowo (West Pomerania), in which church land occupies 1,238 ha and 1,006 ha, respectively. These are also communes with the greatest area of church-owned land at the national scale. This is partly connected with the already mentioned Land Granting Act of 1971, but primarily with churches and denominational associations obtaining the so-called alternative or replacement lands from the Treasury's Agricultural Property Reserve. These are consolidated lands of 


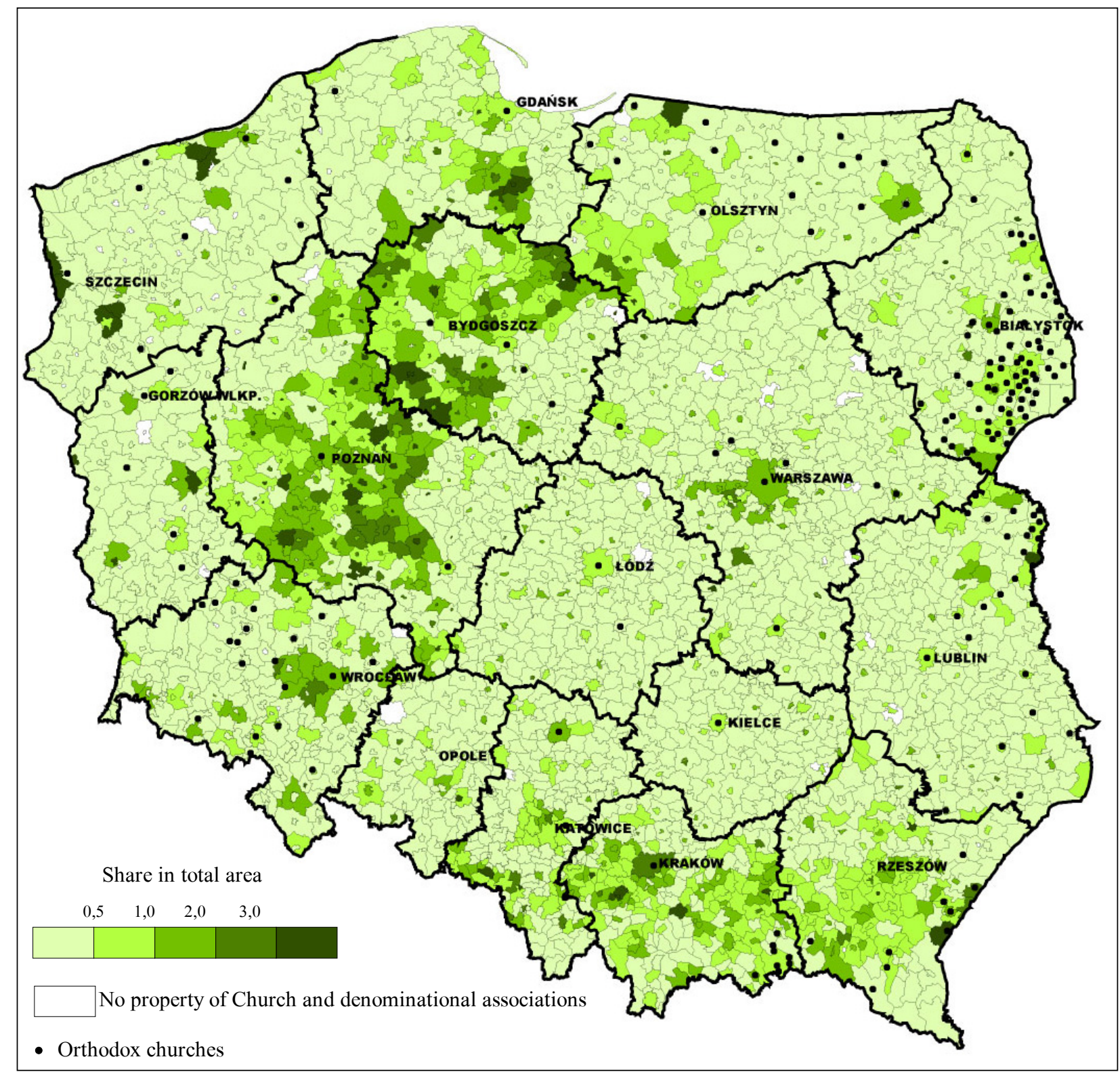

Fig. 2. Property of the Church and denominational associations in 2007

many parishes transferred under the collective jurisdiction of the competent dioceses. Apart from the above areas, the proportion of church property is a major figure only in single communes or their small clusters. One of them is the cluster of communes surrounding Warsaw on the west.

The spatial distribution and size pattern of church land resources that once used to be in the Russian sector are highly characteristic. As has been mentioned, the Czarist authorities used various pretexts, often as a form of reprisal, to confiscate land belonging to the Catholic Church, and the legislation currently in force does not foresee its return. Church property is therefore largely limited to land under ecclesiastical facilities and other areas of religious cult. Church land resources are somewhat bigger in the region along the eastern State border, because here the Church could be offered replacement land from the Treasury Reserve. One might note that this is a region where two churches have their property: Catholic and Orthodox. The Orthodox property consists of small, highly scattered pieces of land, even though there is a marked concentration of Orthodox parishes here (Fig. 2). One of the few major land concentrations given to the Orthodox 
Church for its immovables lost elsewhere is located in the village of Jabłeczna (Sławatycze commune, Fig. 1). On about 600 ha of land, a LublinChełm Diocese farm has been organised here. At Włodawa, in turn, this diocese has been given a former barracks, together with its premises, that will serve to house a convent of nuns.

In the remaining part of the country, the land of the Orthodox church is small in area and scattered. It tends to accompany major settlements of Orthodox believers, which have formed as a result of the displacement of the Ruthenian and Ukrainian population as a result of the 'Action Vistula' after the Second World War. There are also small clusters of Orthodox parishes in Małopolska and Subcarpathia, especially in the regions to which the displaced Orthodox believers have returned and where the recovery of Orthodox church property was possible. Among them are the city of Przemyśl and its vicinity as well as the Low Beskid Mountains in Gorlice poviat.

The dominant use of church land is agricultural, but the relevant figures vary spatially: in 2007 farmland constituted from $55.5 \%$ of ecclesiastical property in Małopolska to $93.2 \%$ in West Pomerania. The reasons for the differences are complex and usually follow from a region's history, its land-use pattern, and the state of the Treasury reserves. Hence, e.g., a high proportion of church-owned woodland in Małopolska, Subcarpathia and Pomerania (Table 2, Fig. 1). In turn, a high proportion of church-owned 'urban land' is characteristic of areas with a great concentration of ecclesiastical and other facilities connected with the activity of churches and denominational associations. This is often again a result of their historical past, which can be observed in Świętokrzyska Land, Łódź and Podlasie, where church property largely concentrates in towns. Among the biggest Polish cities, Cracow owned the greatest portion of church land, at $767 \mathrm{ha}$, followed by Warsaw with its 534 ha.

At this point one might mention ecclesiastical 'recreational grounds'. These are usually small plots of land, the biggest being located in towns. Out of the 36 territorial units in which 'recreational grounds' have 10 hectares and more, 27 are the biggest cities. Most of them can be found in Warsaw - 119 ha, and Łódź - 105 ha (Głębocki 2002, 2005, 2007, 2008).

\section{The ownership structure of church land}

There are similar difficulties with determining the ownership structure of land of the churches and denominational associations. It may resemble that of the early 1950, although in the case of some denominations it can have changed as a result of the political and socio-economic transformation, as evidenced by various, often long-drawn-out conflicts over property between churches or religious groups (Gawryszewski 2005).

In Poland there are about 175 officially registered churches and denominational associations (2005 data). Their role in the country's religious life differs widely, as manifested by the number of their believers, which ranges from a few persons to more than 33 million $^{13}$. The biggest is the Catholic Church, which includes four rites: Latin $(33,862,800$ baptised persons), Byzantine-Ukrainian $(55,000)$, Armenian $(5,000)$, and ByzantineSlavonic (a mere 190) (2006 data; Rocznik ... 2007: 221). Next comes the Polish Autocephalous Orthodox Church with more than 506,800 faithful, of whom over $64 \%$ live in Podlasie. The third is the Association of Jehovah's Witnesses, which is more than 122,700 strong (1996 data) and shows a steady upward tendency. The biggest clusters of its members can be found in Lower Silesia, Silesia, Mazovia, and Wielkopolska (Wyznania religijne ... 1997: 22). . The fourth is the Augsburg Evangelical Church with more than 77,500 believers (2005 data), most of whom (78\%) live in Silesia (Rocznik ... 2007: 221).

As has been mentioned, Jewish communities of the few believers of Judaism living in Poland - 1,229 persons (1996 data; Wyznania religijne ... 1997: 22) - have only small land resources. They can mostly be found in Mazovia, Lower Silesia, Małopolska and the Łódź region. In the interwar period there was a temple in practically every major locality. During the Second World War the systematic extermination of the Jewish population by the Nazi invaders was accompanied by the demolition of all its religious facilities. After

${ }^{13}$ Many churches and denominational associations do not give the number of their faithful for a variety of reasons. Out of those that do, the smallest is the Brotherhood for Learning Judaism (Haworah Lelimud Jahadut); in 2005 it had 9 believers (Wyznania religijne ... 2007). 
the war, those that have survived in the former eastern borderland have come to be located outside the Polish borders. In turn, all major synagogues situated in areas belonging to Germany in the pre-war times were burnt down during the so-called 'Crystal Night' (9th/10th November 1938) and then torn down. In sum, out of the more than 7,000 synagogues in pre-war Poland, a mere 11 have survived ${ }^{14}$. After the war 12 synagogues have been built. Periodically active are also a further four, of which one can mention the Chassidic Chabad Lubavitch synagogue in Warsaw. The extant synagogues and cemeteries are in the care of the Jewish Communities Association as an addition to its religious and welfare activities.

Today, most ecclesiastical land (especially farmland) is leased to, or managed by, nonchurch users. Part of the farmland is cultivated by monastic communities, mostly for their own needs, but there are also some that have started commodity production to meet their maintenance costs. Those are usually monastic establishments located in rural areas or small towns, while it is only in rare cases that land is cultivated by individual parishes or dioceses. Here the examples are the farms of the Gniezno Archdiocese at Kwieciszewo (Kujavia-Pomerania) and of the Orthodox Church at Jabłeczna (Lublin voivodeship).

There are wide differences in the spatial distribution of church land and its use pattern, as has already been mentioned. On the one hand, there is an extensive area embracing the voivodeships of Wielkopolska, Kujavia-Pomerania and partly Pomerania which accounted for nearly one-third of the national ecclesiastical resources in 2007 (Table 2). Another, much smaller concentration, is made up of Małopolska, Subcarpathia, and part of Silesia. Those two concentrations differ also in the land-use pattern. The dominant use in the former is farmland, as against woodland in the latter. A still different use pattern is characteristic of the towns and areas of the former Rus-

${ }^{14}$ These are the Nożyk Synagogue in Warsaw, the Remuh and Tempel Synagogues in Cracow, the Reicher Synagogue in Łódź, the Chewra Nosim and Jeszywas Chachmej Synagogues in Lublin, the White Stork Synagogue in Wrocław, the New Synagogue in GdańskWrzeszcz, Chewra Lomdei Misznajot at OŚwięcim (Auschwitz), Bajs Nusn in Nowy Sącz, and the Synagogue at Bobowa (http://pl.wikipedia.org/ wiki/ Czynne_ synagogi_w_Polsce). sian sector, where urbanised land predominates or constitutes a high proportion of the small resources of church property.

The church land in the above concentrations fully reflects the regions' specific agrarian structure. In Wielkopolska-Pomerania, big farms tend to predominate and the proportion of State (now Treasury) property is high. In Małopolska, in turn, small farms predominate and the share of State property is negligible except in south-eastern Subcarpathia. Those differences result from historical developments that crucially determined the size of land benefices that the donors offered the various churches.

One should note the differences in the policies of the partitioning powers towards the Catholic Church. The policies affected the State-Church relations in Poland when the country regained its independence after the First World War, and their effects have persisted to the present day in the spatial distribution of church property.

In the Prussian and Austrian sectors, confiscation of church land was largely connected with the liquidation of monastic communities and the secularisation of their property. However, land benefices belonging to parishes and dioceses were left intact. In the Russian sector the situation was completely different. After the unsuccessful uprisings, repressions embraced not only their direct participants, but also the Catholic Church for the spiritual and moral support given and its direct involvement in them ${ }^{15}$. The confiscated property was usually given to the Orthodox Church or sold to other users. After Poland regained its independence, the act regulating the State-Church relations as well as the 1925 Concordat with the Vatican State provided that the recovery of the Catholic Church property confiscated by the partitioning powers was to be settled by separate acts. However, despite efforts made in the 1930s this problem failed to be solved. That is why in the eastern regions that used to be in the Russian sector the resources of church land today are small and widely scattered. Worth noting is a marked concentration of ecclesiastical property along the eastern State border in the

${ }^{15}$ About 30 priests were sentenced by courts to death by hanging or firing squad, some 100 to hard labour, and a few hundred were sent into exile (www.zakony.katolik.pl). 
voivodeships of Lublin, Subcarpathia and Podlasie. Those regions are inhabited by a population of the Orthodox denomination, as proved by the many places of worship of the Autocephalous Church that are located there (Fig. 1).

Yet another case is the north-western part of the country. Until the end of the Second World War, the dominant role was played here by the Augsburg Protestant Church, while the Catholic Church was of secondary importance. After the war the situation has changed. As a result of the agreement signed by the great powers in Potsdam (1945), the German population of a predominantly Protestant denomination had to leave Poland. Its place was taken by Polish settlers whose decided majority were Catholic. The population census taken in 1950 showed that nearly a half $(48.8 \%)$ of the residents of the Western and Northern Territories were people who had formerly lived in prewar Polish lands that remained Polish also after the war $^{16}$. The next groups included: repatriants from the USSR and formerly Polish, now Soviet lands $(27.7 \%)$, an indigenous population $(19.7 \%)$, and repatriants and re-emigrants from the western countries (3.8\%).

A substantial proportion of the indigenous population was Protestant, especially among Mazurians, Silesians and that part of the German minority who did not leave Poland, usually for family reasons. Despite this religious diversity, the Catholic Church gained a dominant position in the Western and Northern Territories. However, until 1971 it had no property of its own and was only the user of post-Protestant churches. In 1971 the Catholic Church was granted ownership of only those immovables that were buildings: houses of prayer, other ecclesiastical and housing facilities, and church squares, while land that used to belong to the Protestant and Catholic churches was nationalised as post-German property, in accordance with a decree of 6 September 1946. Lack of information makes it impossible to establish not only the current land resources of Protestant churches, but also their distribution. An indication can be the location of Protestant parishes. Their biggest clusters can be found in Silesia, Opole, Łódź, Warmia-Mazuria and Lower Silesia voivodeships, and in eastern Wielkopolska.

\footnotetext{
${ }^{16}$ In this group was the Ruthenian population displaced after the 'Action Vistula'.
}

After the systemic changes of 1989, limitations on the use of property rights by ecclesiastical legal persons were removed, while the return of, or compensation for, land seized by the communist authorities was guaranteed.

The State's Relation to the Catholic Church Act of 17 May 1989 guaranteed ecclesiastical legal persons the right to acquire, possess and alienate immovable and movable assets, and laid down the principles of the procedures involved (Wileńska 2004). It also defined the rules of recovering the property lost and granting alternative property or a compensation. A 1991 amendment allowed free conveyance of land of a specified area from the Treasury's Agricultural Property Reserve or State Land Fund to ecclesiastical legal persons who undertook activity in the Western and Northern Territories after 8 May 1945. Thanks to those acts and the Concordat with the Vatican State, ecclesiastical legal persons of the Catholic Church and other denominations have become participants of the landed property market. But again, lack of data makes it impossible to establish the scale of transactions concluded. Each decision of ecclesiastical legal persons of the Catholic Church concerning property alienation requires consent of a suitable higher-order unit and has to be approved by institutions of the successive hierarchical rungs (in accordance with the principles laid down in The Code of Canon Law, canon 1292). Currently, the sale of land worth under 1 million euro needs the approval of the Conference of the Polish Episcopate; this, in turn, has to be endorsed by a suitable Vatican Congregation, which is also authorised to make decisions about the alienation of immovables in excess of this worth limit. This is in agreement with the rules of property management. Thus, the global property of the Catholic Church is managed by the Holy See; that of particular Churches, by diocese bishops and other ecclesiastical superiors of an equal rank; parish property, by parish priests; that belonging to institutes of consecrated life and apostolic life associations, by their boards. As to ecclesiastical public persons, they have the right to acquire and alienate earthly possessions, to keep them, administer them, and dispose of them for religious purposes. 


\section{Changes in church land resources over the years 2002-2007}

The process of the recovery of church land has not come to an end yet, although its dynamics is much lower now. In the years 2002-2007 the total area of landed church property grew by 9,395 ha. This figure does not fully reflect the reality, as part of the recovered land had been sold to cover a variety of expenses, e.g. maintenance of the property possessed, necessary new investments, or ecclesiastical, charitable, educational and other type of activity.

In a regional approach, changes in church land resources over the period under analysis varied (Table 3). There were voivodeships where the changes were only slight, but some recorded a substantial increase. The latter included Wielkopolska, Kujavia-Pomerania and WarmiaMazuria, which accounted for $45.9 \%$ of the increase in the church land area. In turn, in Łódź and Małopolska it grew by a mere 106 ha (1.1\%), while in West Pomerania there was even a slight decrease (by 10 ha).

In an approach by commune, changes in the resources of church land are more complex (Fig. 3) owing to the activity of the Property Commission and the participation of ecclesiastical legal persons in transactions on the real-estate market.

In 54 units, there was no church property at both time moments studied, while in the next 12 it had shrunk over this period. Church property had grown in 1,192 units, although in 2002 none was recorded in 33 of them. Church land had dwindled in 701 units, while in 1,094 towns and communes it stayed the same. Those were usually units with small resources of church land, mostly built-up plots or mortmain estate.

It is hard to discern any clear regularities underlying the above changes. One can only note that an increase in church property occurred mostly in areas with substantial Treasury reserves, where

Table 3. Changes in the AREa Of ChurCh land IN the years 2002 AND 2007

\begin{tabular}{|c|c|c|c|c|}
\hline \multirow{2}{*}{ Voivodeship } & \multicolumn{2}{|c|}{ Total area in ha } & \multirow{2}{*}{$\begin{array}{c}\text { Changes } \\
\text { in ha }\end{array}$} & \multirow{2}{*}{$\begin{array}{c}\text { Dynamics } \\
2002=100\end{array}$} \\
\hline & 2002 & 2007 & & \\
\hline Poland & 123,039 & 132,434 & 9,395 & 107.6 \\
\hline Lower Silesia & 6,767 & 7,058 & 291 & 104.3 \\
\hline Kujavia-Pomerania & 15,193 & 16,543 & 1,350 & 108.9 \\
\hline Lublin & 5,926 & 6,906 & 980 & 116.5 \\
\hline Lubuska Land & 3,190 & 3,659 & 469 & 114.7 \\
\hline Łódź & 3,512 & 3,598 & 86 & 102.4 \\
\hline Małopolska & 10,239 & 10,259 & 20 & 100.2 \\
\hline Mazovia & 8,123 & 8,244 & 121 & 101.5 \\
\hline Opole & 1,712 & 2,282 & 570 & 133.3 \\
\hline Podkarpacie & 8,943 & 9,491 & 548 & 106.1 \\
\hline Podlasie & 4,902 & 5,436 & 534 & 110.9 \\
\hline Pomerania & 7,561 & 8,284 & 723 & 109.6 \\
\hline Silesia & 5,029 & 5,507 & 478 & 109.5 \\
\hline Świętokrzyska Land & 2,139 & 2,411 & 272 & 112.7 \\
\hline Warmia-Mazuria & 7,756 & 9,028 & 1,272 & 116.4 \\
\hline Wielkopolska & 23,120 & 24,811 & 1,691 & 107.3 \\
\hline West Pomerania & 8,927 & 8,917 & -10 & 99.9 \\
\hline
\end{tabular}

Source: Own compilation based on data from Land register. Collective lists as of 1 Jan. 2002 and 1 Jan. 2007 by commune. Marshals' Offices of all voivodeships. 


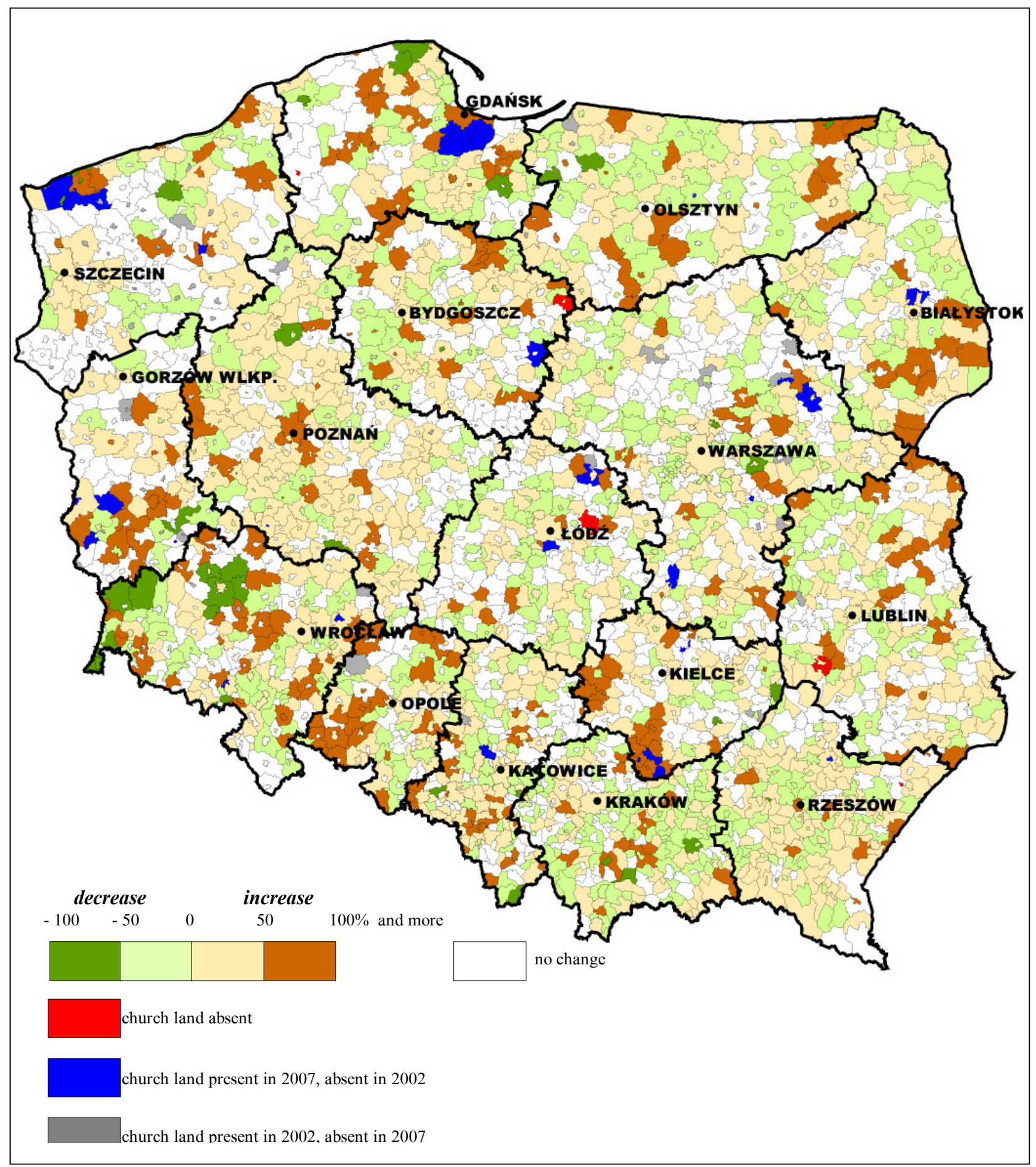

Fig. 3. Changes in church land resources over the years 2002-2007

they often provided replacement land, and in areas where the recovery of property was possible at the place of its location. In turn, a decline in church property is usually recorded in areas where land resources are small and where income from the alienation of land covers essential needs of the local parishes and the activities they conduct. The churches usually sell land that they can dispense with and that often involves high maintenance costs. Church property also dwindled in areas where the restoration process was of the replacement type.

In sum, the above changes result from two facts. On the one hand, the process of ecclesiastical property restoration has not been completed yet, and on the other, churches and denomina- 
tional associations have become active players on the land market. Those facts are also among factors responsible for marked changes in the use pattern of church land (Table 4).

The changes in the use pattern are also due to investment, as reflected in the doubling of built-up areas over the study period. Apart from religious facilities, investments serve other purposes as well, e.g. educational, charitable and economic. The considerable loss of ecclesiastical recreational grounds results primarily from their high maintenance costs. Therefore they are kept at the necessary minimum. In turn, the dwindling of residential areas is generally due to their inclusion into 'other built-up areas', or gradual resignation from separate housing facilities. Also worth noting is the steady increase in the chief components of church property: agricultural land and woodland, despite the fact that they are the main objects alienated.
Another matter worthy of attention is the structure of changes in church land resources over the period 2002-2007 (Table 5). In both the 'net increase' and 'net decrease' categories, territorial units that predominated were ones in which the changes were small, under 5 ha. Those with a net increase constituted $70.2 \%$ of their total number, while the proportion of those with a net decrease was $82.4 \%$. In turn, in terms of the area of land gained or lost, the contribution of those two groups was only slight.

The situation is reversed in the case of territorial units with the highest land increase or decrease. Those in which the increase exceeded 50 ha numbered $85(7.1 \%)$, but their share in the land area amounted to $70.1 \%$. Similar proportions can be observed in units where the land loss exceeded 50 ha: they numbered $24(3.3 \%)$, but their share in the land area was $54.8 \%$.

TABLE 4. CHANGES IN THE USE PATTERN OF CHURCH LAND IN THE YEARS 2002 AND 2007

\begin{tabular}{|c|c|c|c|c|c|}
\hline \multirow{2}{*}{ Land use } & \multicolumn{2}{|c|}{2002} & \multicolumn{2}{|c|}{2007} & \multirow{3}{*}{$\begin{array}{c}\text { Dynamics } \\
2002=100\end{array}$} \\
\hline & ha & $\%$ & ha & $\%$ & \\
\hline$\%$ church land in total area & $\mathbf{x}$ & 0.39 & $x$ & 0.42 & \\
\hline Total church land & 123,039 & 100.0 & 132,434 & 100.0 & 107.6 \\
\hline Of which: agricultural land & 95,341 & 77.5 & 102,060 & 77.1 & 107.0 \\
\hline of which: arable land ${ }^{1}$ & 74,308 & 77.9 & 79,875 & 78.3 & 107.5 \\
\hline orchards $^{1}$ & 1,731 & 1.8 & 1,681 & 1.6 & 97.1 \\
\hline meadows $^{1}$ & 8,695 & 9.1 & 9,471 & 9.3 & 108.9 \\
\hline pastures $^{1}$ & 6,948 & 7.3 & 7,442 & 7.3 & 107.1 \\
\hline other $^{1}$ & 3,659 & 3.8 & 3,590 & 3.5 & 98.1 \\
\hline Woodland and tree clusters & 11,652 & 9.5 & 12,759 & 9.6 & 109.5 \\
\hline Urbanised areas & 12,433 & 10.1 & 14,172 & 10.7 & 114.0 \\
\hline of which: residential areas ${ }^{2}$ & 1,620 & 13.0 & 1,108 & 7.8 & 68.4 \\
\hline industrial areas ${ }^{2}$ & 35 & 0.3 & 54 & 0.4 & 154.3 \\
\hline other built-up areas ${ }^{2}$ & 3,518 & 28.3 & 7,417 & 52.3 & 210.8 \\
\hline urbanised unbuilt areas & 478 & 3.8 & 258 & 1.8 & 54.0 \\
\hline recreation grounds ${ }^{2}$ & 6,409 & 51.5 & 5,040 & 35.6 & 78.6 \\
\hline Other areas & 1,409 & 1.1 & 1,024 & 0.8 & 72.7 \\
\hline Wasteland & 2,002 & 1.6 & 2,106 & 1.6 & 105.2 \\
\hline
\end{tabular}

1 - as per cent of agricultural land; 2 - as per cent of urbanised area. Source: see Table 3 . 
TABLE 5. STRUCTURE OF CHANGES IN CHURCH PROPERTY RESOURCES OVER THE PERIOD 2002-2007

\begin{tabular}{|c|c|c|c|c|c|c|c|c|}
\hline \multirow{3}{*}{$\begin{array}{c}\text { Increase/ } \\
\text { decrease } \\
\text { in ha }\end{array}$} & \multicolumn{4}{|c|}{ Net increase } & \multicolumn{4}{|c|}{ Net decrease } \\
\hline & \multicolumn{2}{|c|}{ territorial units } & \multicolumn{2}{|c|}{ area } & \multicolumn{2}{|c|}{ territorial units } & \multicolumn{2}{|c|}{ area } \\
\hline & number & $\%$ & ha & $\%$ & number & $\%$ & ha & $\%$ \\
\hline Total & 1,192 & 100.0 & 15,749 & 100.0 & 714 & 100.0 & 6,309 & 100.0 \\
\hline $2<$ & 492 & 41.3 & 492 & 3.1 & 374 & 52.4 & 374 & 5.9 \\
\hline $2-5$ & 345 & 28.9 & 941 & 6.0 & 214 & 30.0 & 587 & 9.3 \\
\hline $6-10$ & 92 & 7.7 & 712 & 4.5 & 36 & 5.0 & 270 & 4.3 \\
\hline $11-20$ & 90 & 7.6 & 1,323 & 8.4 & 35 & 4.9 & 543 & 8.6 \\
\hline $21-50$ & 88 & 7.4 & 2,802 & 17.8 & 31 & 4.3 & 1,074 & 17.0 \\
\hline $51-100$ & 55 & 4.6 & 3,771 & 23.9 & 13 & 1.8 & 1,011 & 16.0 \\
\hline$<100$ & 30 & 2.5 & 5,708 & 36.2 & 11 & 1.5 & 2,450 & 38.8 \\
\hline
\end{tabular}

Source: see Table 3 .

\section{Final remarks}

Contrary to the popular opinion about the reputedly vast land resources, especially of the Catholic Church (although it is certainly the dominant owner), the total area of land in possession of all the churches and denominational associations in 2007 was 132,400 ha, or a mere $0.42 \%$ of Poland's area. However, spatial differences are big here: the greatest resources of church land can be found in Wielkopolska and Kujavia-Pomerania, and the smallest, in Opole and Świętokrzyska Land.

Church land has been accumulated over centuries and its resources have constantly kept changing, usually owing to factors of a political nature, whether under Polish authorities or those of the partitioning powers. The Catholic Church suffered especially heavy property losses in the 19th century and after the Second World War, while Jewish communities, as a result of measures taken by the Nazi authorities.

At the national level, the dominant owner of ecclesiastical land is the Catholic Church. However, lack of the relevant statistical data makes it impossible to determine its share, or in general the ownership structure of land belonging to the churches and denominational associations. Presumably, today it resembles that at the start of
1950, that is, from before the takeover of church land by the State on the strength of the act of March 1950 (Table 1).

The remaining churches and denominational associations own little land in comparison with the Catholic Church, and its amount and distribution depend on the number and concentration of their believers. Hence the property of the Autocephalous Orthodox Church is largely concentrated in regions lying along the eastern State border, while that of the Evangelical Churches, in Silesia, Warmia-Mazuria and Łódź voivodeship. In the rest of the country the property of the two Churches is highly scattered, and its small concentrations are connected with the settlement action after the Second World War or with believers not eligible for displacement still living in the old places.

The landed property of Jewish communities is traditionally limited to synagogues, other houses of prayer, and cemeteries. Those are usually small plots of land, scattered throughout the entire country.

The action for the recovery of land of churches and denominational associations slowly draws to a close, on the assumption that the target is the area from the start of 1950.

The churches lease a substantial proportion of their land to other users, less often they use 
it for their own needs. This is mostly farmland cultivated by monastic establishments located in rural areas. Even fewer are large farming estates, like the mentioned farms at Kwieciszewo (the Gniezno Archdiocese) and Jabłeczna (the Orthodox Lublin-Chełm Archdiocese).

On the strength of the acts adopted, and in the case of the Catholic Church also of the Concordat concluded with the Vatican State, the churches can be participants of the land market. Proceeds from the sale of their immovables go to meet their needs, but decisions concerning land alienation must be approved by higher authorities and must obey the law in force in Poland.

\section{References}

DUDZIAK J., 1989. Amortyzacyjne ustawy (Amortisation acts). [Entry in:] Encyklopedia Katolicka, vol. 1. Wydawnictwo Uniwersytetu Katolickiego, Lublin, 463.

GAwrysZewsKi A., 2005. Ludność Polski w XX wieku (Poland's population in the 20th century). IGiPZ PAN, Monografie, 5, Warszawa.

GŁĘBOCKI B., 2002. Struktura własnościowa użytków rolnych w Polsce po 11 latach transformacji gospodarki (Ownership structure of agricultural land in Poland after 11 years of economic transformation). Przeglad Geograficzny $74,3,425-450$.

GŁĘBOCKI B., 2005. Struktura agrarna - zmiany po 12 latach restrukturyzacji polskiego rolnictwa (1990-2002) (Agrarian structure: Changes after 12 years of restructuring of Polish agriculture, 1990-2002). [In:] Głębocki B. (ed.), Struktura przestrzenna rolnictwa Polski u progu XXI wieku. Bogucki Wydawnictwo Naukowe, Poznań, 45-99.

GŁĘBOCKI B., 2007. Rolnictwo (Agriculture). [In:] Rogacki H. (ed.), Geografia spoteczno-gospodarcza Polski. PWN, Warszawa, 185-271.

GŁĘBOCKI B., 2008. Nieruchomości gruntowe własności kościelnej i związków wyznaniowych w Polsce (Landed property of the church and denominational associations in Poland), In: J.J. Parysek, T. Stryjakiewicz (eds.), Region społeczno-ekonomiczny i rozwój regionalny. Bogucki Wydawnictwo Naukowe, Poznań: 315-337.

JABŁOŃSKA-DePtUŁA E., 1987. ... Czyż może historia poptyną́ przeciw prądowi sumień? (Kościót - religia - patriotyzm) 1764-1864 (Can history run counter to the current of conscience? Church, religion, patriotism, 1764-1864). Editions Spotkania. Paryż.

KiENIEWICZ S., 1983. Historia Polski 1795-1918 (History of Poland, 1795-1918). PWN. Warszawa.

KRUKowsKi J., 2002. Kościół a Państwo w Polsce (Okres II Rzeczypospolitej, W Polskiej Rzeczypospolitej Ludowej, W III Rzeczypospolitej) (The Church and the State in Poland. The Second Republic; The Polish People's Republic; The Third Republic). [Entry in:] Encyklopedia Ka- tolicka, vol. I. Wydawnictwo Uniwersytetu Katolickiego, Lublin, 1048-1051.

LeskieWiCZOWA J., 1981. Dobra martwej ręki (Mortmain estate). [Entry in:] Encyklopedia historii gospodarczej Polski do 1945, vol. A-N. Wiedza Powszechna, Warszawa, 139.

Rocznik Statystyczny Rzeczpospolitej Polskiej (Polish Republic's Statistical Yearbook), 2007. GUS, Warszawa.

RyвARCZYK J., 1985. Beneficjum (Benefice). [Entry in:] Encyklopedia Katolicka, vol. 2. Wydawnictwo Uniwersytetu Katolickiego, Lublin, 262-265.

UruszCZAK W., ZARZYCKI Z., 2003. Prawo wyznaniowe (Denominational law). Zakamycze, Kraków.

WILEŃSKA E., 2006. Majątek kościelny (Majątek parafialny, W prawie polskim) (Church property. Parish property in Polish law). [Entry in:] Encyklopedia Katolicka, vol. 11. Wydawnictwo Uniwersytetu Katolickiego, Lublin, 835837.

WisŁocki J. (no date). Uposażenia Kościoła i duchowieństwa katolickiego $w$ Polsce 1918-1939 (Endowment of the Catholic Church and clergy in Poland, 1918-1939). http://www. racjonalista.pl/kk.php/s,5981 (website visited on 12 Oct. 2009).

Wyznania religijne - stowarzyszenia narodowościowe i etniczne $w$ Polsce 1993-1996 (Religious confessions - national and ethnic associations in Poland, 1993-1996). 1997. GUS, Warszawa.

Wyznania religijne. Stowarzyszenia narodowościowe $i$ etniczne $w$ Polsce 2003-2005 (Religious confessions. National and ethnic associations in Poland, 2003-2005). 2007. GUS, Warszawa.

\section{Legal documents}

Act of 20 March 1950 'On the Takeover by the State of Mortmain Estate, Guarantee to Parish Priests of the Possession of Farms, and the Establishment of the Church Fund'. Law Gazette No 9/1950.

Act of 23 June 1971 'On the transition of some immovables situated in the Western and Northern Territories to ecclesiastical legal persons of the Catholic Church and other denominational associations'. Law Gazette No 16/1971.

Act of 17 May 1989 'On guarantees of the freedom of conscience and religion'. Law Gazette No 29/1989.

Act of 17 May 1989 'On the State's relation to the Catholic Church in the Polish Republic'. Law Gazette No 29/1989, and later changes of 1990, 1991 and 1993.

Resolution of the Constitutional Tribunal of 24 June 1992. Law Gazette No 52/1992.

The Code of Canon Law, 1983.

Concordat between the Vatican State and the Polish Republic, 10 February 1925. Law Gazette No 72/1925.

Concordat between the Vatican State and the Polish Republic, 28 July 1993. Law Gazette No 51/1998.

Online documents

Projekt ustawy o zniesieniu Funduszu Kościelnego. Retrieved April 21, 2008, from http://www.senat.gov.pl/ K5/DOK/dr/750/771.htm 